\title{
Quantification of carbon dioxide and methane emissions in urban areas: source apportionment based on atmospheric observations
}

\author{
Miroslaw Zimnoch ${ }^{1}$ (D) - Jaroslaw Necki ${ }^{1}$. \\ Lukasz Chmura $^{1,2}$ • Alina Jasek ${ }^{1,2}$ - Dorota Jelen ${ }^{1}$. \\ Michal Galkowski ${ }^{1}$ - Tadeusz Kuc ${ }^{1}$. \\ Zbigniew Gorczyca $^{1} \cdot$ Jakub Bartyzel $^{1}$. \\ Kazimierz Rozanski ${ }^{1}$
}

Received: 10 May 2017 / Accepted: 29 May 2018 / Published online: 12 June 2018

(C) The Author(s) 2018

\begin{abstract}
Anthropogenic emissions of carbon dioxide $\left(\mathrm{CO}_{2}\right)$ and methane $\left(\mathrm{CH}_{4}\right)$ in the atmosphere constitute an important component of the related carbon budget. The main source of anthropogenic $\mathrm{CO}_{2}$ is burning of fossil fuels, especially in densely populated areas. Similar emissions of $\mathrm{CH}_{4}$ are associated with the agricultural sector, coal mining, and other human activities, such as waste management and storage and natural gas networks supplying methane to large urban, industrial centers. We discuss several methods aimed at characterizing and quantifying atmospheric loads and fluxes of $\mathrm{CO}_{2}$ and $\mathrm{CH}_{4}$ in Krakow, the second largest city in Poland. The methods are based on atmospheric observations of mixing ratios as well as isotopic composition of the investigated gases. Atmospheric mixing ratios of $\mathrm{CO}_{2}$ and $\mathrm{CH}_{4}$ were measured using gas chromatography (GC) and cavity ring-down spectroscopy (CRDS). The isotopic composition of $\mathrm{CO}_{2}$ and $\mathrm{CH}_{4}$ was analyzed using isotope ratio mass spectrometry (IRMS), accelerator mass spectrometry (AMS), and CRDS techniques. These data, combined with auxiliary information characterizing the intensity of vertical mixing in the lower atmosphere (height of the nocturnal boundary layer [NBL] and atmospheric ${ }^{222} \mathrm{Rn}$ concentration), were further used to quantify emission rates of $\mathrm{CO}_{2}$ and $\mathrm{CH}_{4}$ in the urban atmosphere of Krakow. These methods provide an efficient way of quantifying surface emissions of major greenhouse gases originating from distributed sources, thus complementing the widely used bottom-up methodology based on emission statistics.
\end{abstract}

Miroslaw Zimnoch

zimnoch@agh.edu.pl

1 Faculty of Physics and Applied Computer Science, AGH University of Science and Technology, Al. Mickiewicza 30, PL-30-059 Krakow, Poland

2 Branch of Krakow, IMGW Institute of Meteorology and Water Management, Krakow, Poland 
Keywords Anthropogenic emissions · Carbon dioxide · Methane · Source apportionment · Urban environment $\cdot$ Krakow agglomeration

\section{Introduction}

The dynamics of the Earth's carbon cycle is being studied with growing intensity across multiple temporal and spatial scales (Le Quéré et al. 2015). The overarching goal of these studies is a deeper understanding of this cycle, in particular better quantification of carbon exchange between the atmosphere and the Earth's surface in response to anthropogenic emissions of carbon dioxide and methane, the two main anthropogenic greenhouse gases. From this perspective, urbanized and industrialized regions of the northern hemisphere play an important role, as they are responsible for the majority of anthropogenic emissions of carbon to the atmosphere (Boden and Anders 2015; Turnbull et al. 2011; Gioli et al. 2012; McKain et al. 2012; Kotthaus and Grimmond 2012; Liu et al. 2012; McMeeking et al. 2012). The European continent, with its dense transportation network, developed industrial infrastructure, and high population density is currently responsible for almost $10 \%$ of the global fossil fuel carbon dioxide $\left(\mathrm{CO}_{2}\right)$ emissions (Edgar 2015). Urban agglomerations are also an important source of methane $\left(\mathrm{CH}_{4}\right)$. It has been estimated that aging natural gas distribution networks are leaking at a rate of up to $8 \%$ of the total gas consumption (Alvarez et al. 2014). Several projects have been performed in different urban environments in Europe. For example, Demény and Haszpra (2002) studied a stable carbon isotope composition of $\mathrm{CO}_{2}$ in background air (Hegyhátsál and K-puszta, Hungary) and compared it to two localities in the area of a major pollution source. They demonstrated a constant ${ }^{13} \mathrm{C}$ composition of a background $\mathrm{CO}_{2}$ in the region; however, complex diurnal and seasonal variability attributed to fractionation processes during biological activity (Demény and Haszpra 2002). Widory and Javoy (2003) studied the carbon isotope composition of atmospheric $\mathrm{CO}_{2}$ in Paris. They applied the combined isotope and concentration method to study different pollution sources in the first few meters above ground. The results showed that air pollution in this layer results mainly from vehicles (ca. 90\% of the total). An interesting element was the assessment of human respiration contribution into the atmospheric load (Widory and Javoy 2003). An application of atmospheric ${ }^{14} \mathrm{C}$ measurement for estimation of fossil fuel emission into the atmosphere in regional scale was demonstrated by Levin et al. (2003), and the example of application of this method in urban area has been demonstrated by Molnar et al. (2010). Based on measurements in Debrecen and a rural site (Hegyhatsal) as a background, authors calculated the annual variation of fossil fuel $\mathrm{CO}_{2}$ component for the city. In Poland, application of the ${ }^{13} \mathrm{C}$ isotope composition regarding the investigation of atmospheric $\mathrm{CO}_{2}$ and dissolved inorganic carbon in precipitation water for the urban area of Wroclaw was demonstrated by Górka et al. (2011). No statistical correlation was observed between the concentration and $\delta^{13} \mathrm{C}$ value of atmospheric $\mathrm{CO}_{2}$ and dissolved inorganic carbon (DIC) in precipitation by the authors. This team assessed the natural and anthropogenic contributions of $\mathrm{CO}_{2}$ on the urban atmosphere of Wroclaw City (SW Poland) with combined quantitative $\left(\mathrm{CO}_{2}\right.$ concentrations) and qualitative analysis $\left(\delta^{13} \mathrm{C}\right.$ of $\left.\mathrm{CO}_{2}\right)$ (Górka and Lewicka-Szczebak 2013).

Global emissions of carbon dioxide from fossil fuel burning and cement production have increased by about 58\%, from 6.2 PgC in 1990 to $9.8 \mathrm{PgC}$ in 2014 (Le Quéré et al. 2015). This growth highlights a general failure of the Kyoto Protocol that was aimed at a significant reduction of $\mathrm{CO}_{2}$ emissions relative to 1990 , rather than an increase. The reference method 
used for determination of emissions is based on statistical data reported by signatory countries of the United Nations Framework Convention on Climate Change (UNFCCC) and represents the country level. The uncertainty of greenhouse gas emissions at the regional level is significantly higher than at the country level (Danylo et al. 2015). To improve the quality of emission data at a regional and local scale, several disaggregation methods based on statistical analysis using several proxies (e.g., population density), geographic information system (GIS) methods, questionnaires, and interviews are used (Bun et al. 2018; Rosicki and Załupka 2015). It is clear that for future strategies towards controlling carbon emissions at the regional and local scales to be successful, independent, science-driven methods for quantifying emissions of greenhouse gases in the atmosphere must be developed and implemented (Gurney 2013). The top-down approach based on atmospheric observations of the greenhouse gas mixing ratio is an example of an independent method. There may be some synergy in combining top-down and bottom-up approaches, based on different independent data sources. In addition, the topdown approach delivers data as input for inverse modeling, allowing an extension of the flux assessment for larger areas (regions, countries).

Here, we present a brief overview of long-term investigations aimed at quantification of atmospheric loads and fluxes of $\mathrm{CO}_{2}$ and $\mathrm{CH}_{4}$ in Krakow's agglomeration, using atmospheric observations combined with ground-level measurements and modeling (Kuc et al. 2003; Zimnoch et al. 2010; Zimnoch et al. 2012; Zimnoch et al. 2014). Presented methods link different disciplines, including atmospheric mixing ratio measurements, application of the natural isotope tracers, boundary layer dynamics study, and numerical modeling. In the first part, we demonstrate how measurements of atmospheric mixing ratios of carbon dioxide, combined with analyses of its carbon isotope composition $\left({ }^{13} \mathrm{C} /{ }^{12} \mathrm{C}\right.$ and ${ }^{14} \mathrm{C} /{ }^{12} \mathrm{C}$ ratios), can be used to partition the local atmospheric $\mathrm{CO}_{2}$ budget and quantify the contribution of fossil fuel derived $\mathrm{CO}_{2}$ in the local atmosphere. In the second part, we present two independent methods of assessing surface fluxes of $\mathrm{CO}_{2}$ and $\mathrm{CH}_{4}$ originating from distributed sources. Typical for urban regions are generally elevated concentrations of $\mathrm{CO}_{2}$ and $\mathrm{CH}_{4}$ in the local atmosphere, compared to remote, clean areas (Chmura et al. 2008; Rozanski et al. 2014). These local loads are caused by intense surface emissions of $\mathrm{CO}_{2}$ and $\mathrm{CH}_{4}$ from both point and distributed sources. When combined with diurnal variations in the intensity of vertical mixing of the lower atmosphere, they often lead to characteristic variations in atmospheric concentrations of $\mathrm{CO}_{2}$, $\mathrm{CH}_{4}$, and ${ }^{222} \mathrm{Rn}$ in the urban atmosphere, with high levels of those gases recorded during the night and reduced concentrations during the midday and afternoon hours. This diurnal variability can be used to quantify the surface fluxes of those gases.

\section{Material and methods}

\subsection{Site description}

The presented $\mathrm{CO}_{2}$ and $\mathrm{CH}_{4}$ source apportionment and emission assessment methods were tested in the urban area of Krakow, the second largest city in Poland. Krakow has an urban agglomeration of about one million inhabitants, located in the Vistula River Valley in the southern part of the country, approximately $100 \mathrm{~km}$ north of the Tatra Mountains. The valley is oriented along the west-east direction and surrounded by hilly terrain from the south and flat upland areas from the north. The elevation of the city is approximately $200 \mathrm{~m}$ a.s.1., while the tops of the surrounding hills reach $250-300 \mathrm{~m}$ a.s.l. Weak winds blowing along the valley 
(average wind speed calculated for the period of 2005 to 2009 was approximately $3.3 \mathrm{~m} \mathrm{~s}^{-1}$ ), frequent calm periods with the wind speed below $1 \mathrm{~m} \mathrm{~s}^{-1}$ (ca. $36 \%$ of the time period mentioned above), and frequent temperature inversions in the lower atmosphere, often extending over several days during the winter, constitute typical features of the local climate. These factors favor accumulation of trace gases emitted by local sources within the boundary layer over the city. The monthly mean air temperature shows a distinct seasonal variation with maximum values of $20-25{ }^{\circ} \mathrm{C}$ recorded in July and August and minimum of $-5-0{ }^{\circ} \mathrm{C}$ in January and February. Monthly precipitation has a weak seasonal cycle with the maximum of ca. $65 \mathrm{~mm}$ during the summer and the minimum of around $25 \mathrm{~mm}$ during the winter.

The anthropogenic emissions of $\mathrm{CO}_{2}$ within the city limits result from the burning of coal, oil, and natural gas for communal purposes, steadily growing car traffic and industry. There are still more than 23,000 old-fashioned stoves used in the city (Monit-Air 2016). The total number of cars registered in Krakow region from 2010 to 2014 has increased by 14\% (GUS 2016). In addition, there are three large power plants and a large metallurgical factory within $50-\mathrm{km}$ radius from the city center. With prevailing westerly circulation, the Krakow region is under substantial influence of large coal mining and the industrial district (Upper Silesia), located approximately $60 \mathrm{~km}$ west of the city. Anthropogenic emissions of $\mathrm{CH}_{4}$ are associated mainly with natural gas distribution networks, especially dense and potentially leaking in urban centers and numerous landfills in the region.

Measurements of atmospheric $\mathrm{CO}_{2}$ and $\mathrm{CH}_{4}$ mixing ratios, complemented by measurements of isotopic composition of $\mathrm{CO}_{2}$ and atmospheric radon concentration, were conducted in the western part of the city $\left(50^{\circ} 04^{\prime} \mathrm{N}, 19^{\circ} 55^{\prime} \mathrm{E}, 220 \mathrm{~m}\right.$ a.s.l.) at a distance of $2 \mathrm{~km}$ from the city center, on the campus of the AGH University of Science and Technology (Fig. 1). The campus is surrounded by recreation and sports grounds. Air intake was located on the roof of the Faculty of Physics and Applied Computer Science building, at an elevation of $20 \mathrm{~m}$ in case of radon and gas chromatographic measurements and $40 \mathrm{~m}$ above local ground in case of CRDS analyzer. Mixing height within the nocturnal boundary layer (NBL) was monitored using the vertical Doppler sodar system (VDS), built by the Krakow Branch of the Institute of Meteorology and Water Management (Netzel et al. 1995) and operated inside the park complex between the city center and the industrial district, at a distance of ca. $6 \mathrm{~km}$ east of the location of the main measurement site. Sodar records were analyzed manually. Stability of the surface layer was identified through unique features of sodar echoes, and its range was defined by determining the height of observed structures at the upper level, where mixing processes still exist (Piringer and Joffre 2005). To examine possible influences of the distance between sodar and mixing ratio measurement sites, two dedicated measurement campaigns were conducted. The first was performed in August 2008, when the $\mathrm{CO}_{2}$ mixing ratio measurements were moved to the sodar location. From March to May 2009, the second campaign was conducted, when the sodar system was moved to the GC system. No significant change in the mixing layer height variability or the range of calculated fluxes was observed (Zimnoch et al. 2010).

\subsection{Methodology}

\subsubsection{Partitioning of $\mathrm{CO}_{2}$ budget in the urban atmosphere}

Concentration of carbon dioxide in the urban atmosphere is controlled by intensity of vertical mixing in the planetary boundary layer (PBL), horizontal transport by wind, and the strength 


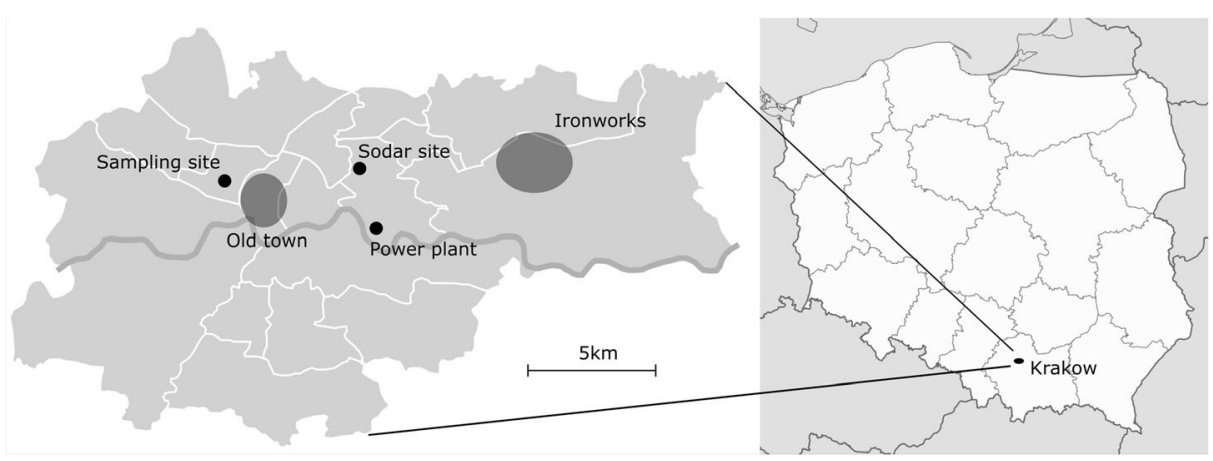

Fig. 1 Location of the measurement point, sodar site, and characteristic objects in Krakow (power plant, ironworks, and old town location)-left panel. Location of Krakow on the map of Poland - right panel

of local $\mathrm{CO}_{2}$ sources and sinks. While variability of boundary layer mixing, as well as horizontal advection processes, dissolves local emissions by remote air-they control the contribution of the background component in local atmospheric balance. In the case of different sources and sinks of this gas, they are usually characterized by different isotope signatures; thus, their contribution in the atmospheric load controls the resultant isotopic composition of this trace gas in the atmosphere. The following mass and isotope balance equations, facilitating source attribution of the measured $\mathrm{CO}_{2}$ load in the local atmosphere, can be formulated:

$$
\begin{gathered}
c_{a t m=} c_{b g+} c_{b i o+} c_{\text {foss }}, \\
c_{a t m} \cdot \delta^{13} C_{a t m}=c_{b g} \cdot \delta^{13} C_{b g}+c_{b i o} \cdot \delta^{13} C_{b i o}+c_{f o s s} \cdot \delta^{13} C_{\text {foss }}, \\
c_{a t m} \cdot \Delta^{14} C_{a t m}=c_{b g} \cdot \Delta^{14} C_{b g}+c_{b i o} \cdot \Delta^{14} C_{b i o}+c_{\text {foss }} \cdot \Delta^{14} C_{\text {foss }},
\end{gathered}
$$

where:
$c_{\text {atm }} \quad$ measured $\mathrm{CO}_{2}$ mixing ratio in the local atmosphere (ppm),
$c_{b g} \quad \mathrm{CO}_{2}$ mixing ratio in the regional background air (ppm),
$c_{\text {bio }} \quad$ biogenic $\mathrm{CO}_{2}$ contribution (ppm),
$c_{\text {foss }}$ fossil fuel derived $\mathrm{CO}_{2}$ contribution (ppm),
$\delta^{13} C_{a t m}{ }^{13} \mathrm{C}$ isotope composition of $\mathrm{CO}_{2}$ in the local atmosphere (\%o),
$\delta^{13} C_{b g} \quad{ }^{13} \mathrm{C}$ isotope composition of $\mathrm{CO}_{2}$ in the regional background air (\%o),
$\delta^{13} C_{b i o} \quad{ }^{13} \mathrm{C}$ isotope composition of biogenic $\mathrm{CO}_{2}$ source (\%o),
$\delta^{13} C_{a n t}{ }^{13} \mathrm{C}$ isotope composition of fossil fuel derived $\mathrm{CO}_{2}$ source (\%o),
$\Delta^{14} C_{a t m}{ }^{14} \mathrm{C}$ isotope composition of $\mathrm{CO}_{2}$ in the local atmosphere (\%o),
$\Delta^{14} C_{b g} \quad{ }^{14} \mathrm{C}$ isotope composition of $\mathrm{CO}_{2}$ in the regional background air (\%o),
$\Delta^{14} C_{b i o} \quad{ }^{14} \mathrm{C}$ isotope composition of biogenic $\mathrm{CO}_{2}$ source (\%o),
$\Delta^{14} C_{a n t} \quad{ }^{14} \mathrm{C}$ isotope composition of fossil fuel derived $\mathrm{CO}_{2}$ source $(\%$ ) $)$.

The measured ${ }^{13} \mathrm{C} /{ }^{12} \mathrm{C}$ ratios are expressed in delta notation on the VPDB scale (Coplen 1996): 


$$
\delta^{13} C=\left(\frac{R_{s a}}{R_{s t}}-1\right) \cdot 1000(\% \circ)
$$

where:

$R_{\text {sa }}{ }^{13} \mathrm{C} /{ }^{12} \mathrm{C}$ ratio in sample,

$R_{\text {st }} \quad{ }^{13} \mathrm{C} /{ }^{12} \mathrm{C}$ ration in reference standard,

while the radiocarbon content is expressed in capital delta notation, corrected for isotope fractionation, relative to the oxalic acid standard, and normalized for the year 1950 (Mook and van der Plicht 1999):

$$
\Delta^{14} C=\left[\frac{A_{s a}}{A_{s t}} \cdot\left(\frac{0.975}{1+\delta^{13} \mathrm{C}}\right)-1\right] \cdot 1000(\%),
$$

where:

$A_{s a}$ radiocarbon activity in sample,

$A_{s t}$ radiocarbon activity in reference standard,

$\delta^{13} \mathrm{C} \quad{ }^{13} \mathrm{C}$ isotopic composition of sample.

Source apportionment of the total $\mathrm{CO}_{2}$ load in the urban atmosphere with the aid of Eqs. (1)-(3) requires measurements of atmospheric mixing ratios of this gas, as well as its carbon isotope composition $\left(\delta^{13} C\right.$ and/or $\left.\Delta^{14} C\right)$. Also, a priori knowledge of isotopic signatures of the $\mathrm{CO}_{2}$ sources is necessary.

Identification of the dominant $\mathrm{CO}_{2}$ source in the local atmosphere, based on stable isotope composition of this gas, was first demonstrated by Keeling (1960). Using the mass and isotope balance approach, he found that in the case of two-component mixing $\left(\mathrm{CO}_{2}\right.$ in the background atmosphere mixes with $\mathrm{CO}_{2}$ emitted by the mean local source), there is a linear relationship between the ${ }^{13} \mathrm{C} /{ }^{12} \mathrm{C}$ ratio in atmospheric $\mathrm{CO}_{2}$ (expressed in delta notation) and reciprocity of its atmospheric mixing ratio, according to the equation:

$$
\delta^{13} C_{a t m}=\left[c_{b g} \cdot\left(\delta^{13} C_{b g}-\delta^{13} C_{s r c}\right)\right] \cdot \frac{1}{c_{a t m}}+\delta^{13} C_{s r c},
$$

where:

$\delta^{13} C_{s r c}{ }^{13} \mathrm{C}$ isotope composition of local $\mathrm{CO}_{2}$ source.

The isotopic signature of the local $\mathrm{CO}_{2}$ source $\left(\delta^{13} \mathrm{C}_{\mathrm{src}}\right)$ can be calculated when the time series of the mixing ratio and $\delta^{13} \mathrm{C}$ values of atmospheric $\mathrm{CO}_{2}$ are available. Recent developments of laser-based spectrometric techniques facilitate such measurements and enable application of this approach to monitor isotopic signature of local sources of $\mathrm{CO}_{2}$ or other trace gases, such as $\mathrm{CH}_{4}$ or $\mathrm{N}_{2} \mathrm{O}$ in various environments (Tuzson et al. 2011; Vogel et al. 2013).

Application of the Keeling method to a 3-year record (2011 to 2014) of continuous $\mathrm{CO}_{2}$ and $\delta^{13} \mathrm{CO}_{2}$ measurements performed in Krakow, using the Picarro G2101-i CRDS instrument enabled characterization of short-term and seasonal variability of $\delta^{13} \mathrm{C}$ isotope signature of the mean local $\mathrm{CO}_{2}$ source. The data were analyzed on a daily basis and presented in Sect. 3.1. Each data point presented in Fig. 2 was calculated using Eq. (6) applied to the measurement data covering 24-h periods (from midnight to midnight). 
Days for which the standard deviation of the diurnal mean $\mathrm{CO}_{2}$ mixing ratio was lower than $10 \mathrm{ppm}$ and were not considered in the calculation. Similar calculations based on the Keeling method were applied to measurements of the methane concentration and its carbon isotope composition in the urban atmosphere of Krakow from 1996 to 1997. Mixing ratios of $\mathrm{CH}_{4}$ were measured with gas chromatography (GC), whereas isotope ratio mass spectrometry (IRMS) was used for $\delta^{13} \mathrm{C}_{\mathrm{CH} 4}$ measurements, after appropriate preparation of the samples (Miroslaw 1997).

When more than one type of local $\mathrm{CO}_{2}$ sources is considered, the Keeling approach assumes two-component mixing to only characterize isotopically the mean local source of this gas. More detailed calculation of atmospheric $\mathrm{CO}_{2}$ budget, enabling quantitative source partitioning and accounting for more than one type of local $\mathrm{CO}_{2}$ sources (e.g., biospheric respiration and fossil fuel emissions), requires additional information. One of the possibilities is including an additional isotope balance equation into the system, related to other isotope tracers linked to $\mathrm{CO}_{2}$ molecules such as radiocarbon $\left({ }^{14} \mathrm{C}\right)$ or heavy isotopes of oxygen $\left({ }^{18} \mathrm{O}\right)$. It has been demonstrated by several authors that radiocarbon is an excellent tool for studying anthropogenic contribution to atmospheric $\mathrm{CO}_{2}$, originating from the burning of fossil fuels (de Jong and Mook 1982; Meijer et al. 1996; Levin et al. 2003; Levin et al. 2008). Carbon dioxide in the background atmosphere contains radiocarbon, radioactive carbon isotope with a half-life of 5730 years, originating from atmospheric nuclear bomb tests conducted in the $60 \mathrm{~s}$ and $70 \mathrm{~s}$ of the twentieth century. It also contains ${ }^{14} \mathrm{C}$, which is continuously produced in the upper atmosphere by cosmic-ray induced nuclear reactions with atmospheric nitrogen. Carbon present in coal, oil, and natural gas is devoid of radiocarbon due to a very long storage period of these fuels in geological formations. Such fossil $\left({ }^{14} \mathrm{C}\right.$-free $)$ carbon is emitted into the atmosphere in the form of $\mathrm{CO}_{2}$ during the combustion process and reduces the natural abundance of ${ }^{14} \mathrm{C}$. A large contrast in the abundance of this isotope in fossil-fuel derived $\mathrm{CO}_{2}$ emissions and the background atmosphere yields this balance method to be extremely sensitive. Equations (1) and (3) can be

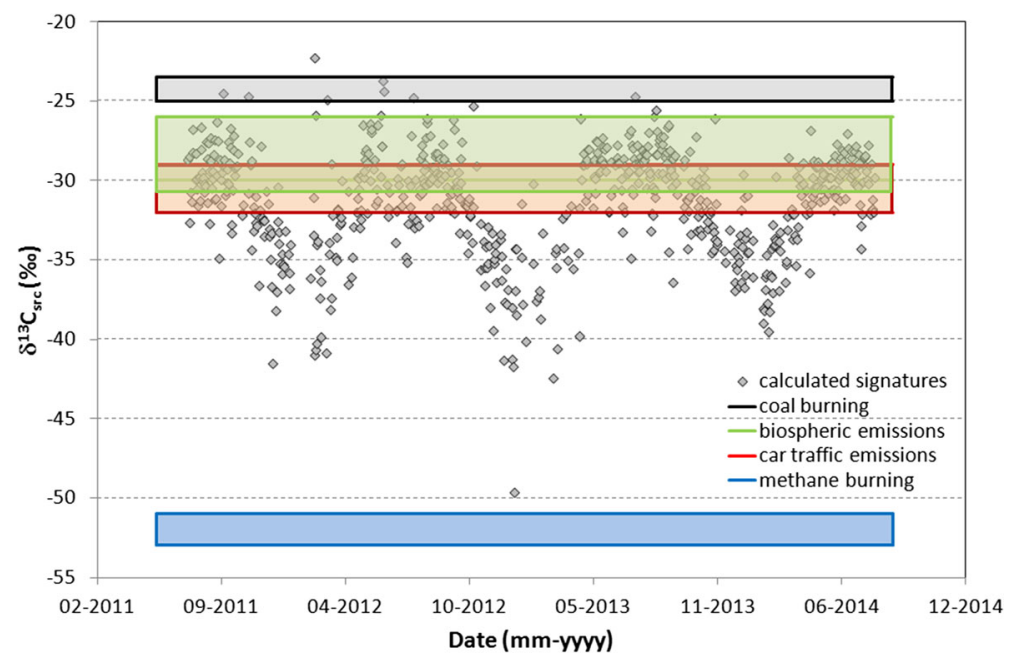

Fig. 2 Seasonal variability of carbon isotope signature $\left(\delta^{13} \mathrm{C}_{\mathrm{src}}\right)$ of mean $\mathrm{CO}_{2}$ source in Krakow from 2011 to 2014. Rectangles represent ranges of $\delta^{13} \mathrm{C}$ values of $\mathrm{CO}_{2}$, emitted from major sources of this gas in the city 
solved for $\mathrm{c}_{\text {foss }}$ and $\mathrm{c}_{\mathrm{bio}}$ in the local atmosphere, if all other parameters are measured or can be reliably assessed according to equations:

$$
c_{\text {foss }}=c_{a t m} \cdot \frac{\Delta^{14} C_{b g}-\Delta^{14} C_{a t m}}{\Delta^{14} C_{b g}+1000},
$$

and

$$
c_{\text {bio }}=c_{\text {atm }}-c_{b g}-c_{\text {foss }} \text {, }
$$

where:

$c_{\text {atm }} \quad \mathrm{CO}_{2}$ mixing ratio measured in the local atmosphere (ppm),

$c_{b g} \quad \mathrm{CO}_{2}$ mixing ratio in the regional background air (ppm),

$c_{\text {bio }} \quad$ contribution of the biogenic component ( $\left.\mathrm{ppm}\right)$,

$c_{\text {foss }} \quad$ contribution of the fossil-fuel derived component ( $\left.\mathrm{ppm}\right)$,

$\Delta^{14} C_{a t m}{ }^{14} \mathrm{C}$ isotope composition of $\mathrm{CO}_{2}$ in atmospheric sample (\%o),

$\Delta^{14} C_{b g} \quad{ }^{14} \mathrm{C}$ isotope composition of $\mathrm{CO}_{2}$ in the regional background air (\%o).

Equations (7)-(8) were derived from the assumption that radiocarbon content in the biospheric and background $\mathrm{CO}_{2}$ is identical $\left(\Delta^{14} C_{b i o}=\Delta{ }^{14} C_{b g}\right)$, and the fossil $\mathrm{CO}_{2}$ component contains no radiocarbon $\left(\Delta^{14} C_{\text {foss }}=-1000 \%\right.$ o).

As indicated, radiocarbon is a unique tracer to quantify the contribution of fossil-fuel derived $\mathrm{CO}_{2}$ from the budget of this gas in the local atmosphere. When regional background levels of $\mathrm{CO}_{2}$ are known or assessed, the isotope mass balance equations calculate the biospheric component of the budget. Two examples of $\mathrm{CO}_{2}$ source partitioning from radiocarbon analysis are then applied to different time scales and are seen in the second part of Sect. 3.1.

The first example illustrates the use of Eqs. (7) and (8) for apportionment of $\mathrm{CO}_{2}$ sources in the local atmosphere of Krakow. In this case, monthly means of $\mathrm{CO}_{2}$ mixing ratios and their carbon isotopic composition are derived for air samples collected in Krakow from 2005 to 2010, which were then analyzed. The measurements of $\mathrm{CO}_{2}$ mixing ratios were performed using automatic gas chromatograph HP6890 (Necki et al. 2003), while the radiocarbon content in the local atmosphere was determined using weekly cumulative $\mathrm{CO}_{2}$ samples collected with a molecular sieve and analyzed by the liquid scintillation technique (Kuc 1991). Typical uncertainty of $\mathrm{CO}_{2}$ mixing ratio measurements and $\Delta^{14} \mathrm{C}$ analyses was on the order of $0.1 \mathrm{ppm}$ and $5 \%$, respectively. Details of the adopted methodology can be found in Zimnoch et al. (2012).

From 2007 to 2009, several measurement campaigns were conducted with the main aim being to investigate diurnal variability of the $\mathrm{CO}_{2}$ budget in the urban atmosphere of Krakow (Jelen 2012). Air samples for the mixing ratio and isotopic analyses of $\mathrm{CO}_{2}$ were collected with an hourly resolution. During each campaign, five to seven air samples were collected. Mixing ratio measurements of $\mathrm{CO}_{2}$ in the collected samples used GC. After the mixing ratio measurement, carbon dioxide was cryogenically extracted from collected air samples for further isotope analyses, using IRMS and AMS techniques to determine the isotopic composition of carbon $\left(\delta^{13} \mathrm{C}\right.$ and $\Delta^{14} \mathrm{C}$ ) (Zimnoch et al. 2004; Goslar and Czernik 2000). Overall uncertainty of isotope measurements was on the order of $0.2 \%$ for $\delta^{13} \mathrm{C}$ and $0.7 \%$ for $\Delta^{14} \mathrm{C}$. As background concentrations of radiocarbon, the data available from the Kasprowy Wierch station, ca. $100 \mathrm{~km}$ south of Krakow, located on top of the Kasprowy Wierch Mountain in the Polish Tatras (1989 m a.s.l) were used. This station is considered to be a regional background station, free of local influences (Necki et al. 2003). 
2.2.2 Top-down assessment of $\mathrm{CO}_{2}$ and $\mathrm{CH}_{4}$ fluxes using measurements of atmospheric ${ }^{222} \mathrm{Rn}$ concentrations

During the day, when thermal convection operates in the lower atmosphere, trace gases emitted from the surface are diluted in a large volume of the well-mixed layer of the PBL, leading to relatively low concentrations of those gases at the level close to the urban canopy height (we neglect street canyon effects). Inversion of the vertical temperature profile in the lower atmosphere during the late afternoon leads to a drastic reduction of the intensity of vertical mixing and subsequent accumulation of trace gases in the near-ground atmosphere.

Radon-222 is a radioactive inert gas produced by the decay of ${ }^{226} \mathrm{Ra}$. Radium-226, belonging to the ${ }^{238} \mathrm{U}$-series, is ubiquitous in the Earth's crust and in soil. Radon-222 diffuses from the soil into the atmosphere where it decays to lead ${ }^{210} \mathrm{~Pb}$, via a chain of intermediate decay products. The flux of ${ }^{222} \mathrm{Rn}$ into the atmosphere is controlled by the ${ }^{226} \mathrm{Ra}$ content in the soil, physical properties of the upper soil layer, and to some extent by physical parameters characterizing the soil-atmosphere interface (Levin et al. 2002). Due to lack of important sinks apart of radioactive decay, ${ }^{222} \mathrm{Rn}$ is an excellent tracer for the evaluation of atmospheric transport models (Dörr et al. 1983; Gupta et al. 2004; Zhang et al. 2011).

Assuming spatially homogeneous and known constant flux of radon into the atmosphere, it is possible to determine the flux of other trace gases emitted from the Earth's surface, based on parallel measurements of the concentration increase of ${ }^{222} \mathrm{Rn}$ and the analyzed trace gas in the near-ground atmosphere during nocturnal inversion (Levin et al. 1999):

$$
\frac{d c_{x}}{d c_{R n}}=\frac{f_{x}}{f_{R n}},
$$

where:

$\frac{d c_{x}}{d c_{R n}} \quad$ the slope of the linear relationship between the measured mixing ratios of the investigated gas and radon,

$f_{x} \quad$ surface flux of the investigated gas (e.g., $\mathrm{CO}_{2}$ or $\mathrm{CH}_{4}$ ),

$f_{R n} \quad$ flux of radon into the atmosphere (known or assumed).

Calculations of surface night fluxes of $\mathrm{CO}_{2}$ and $\mathrm{CH}_{4}$, based on simplified atmospheric budget and parallel measurements of atmospheric radon concentrations, were done from 2005 to 2009 according to the methodology above. The method assumes a predetermined level of surface radon flux and seasonal variability. The radon flux is assumed to fluctuate with the season, with maximum values of ca. $60 \mathrm{~Bq} \mathrm{~m}^{-2} \mathrm{~h}^{-1}$ in September and October and minimum values of ca. $35 \mathrm{~Bq} \mathrm{~m}^{-2} \mathrm{~h}^{-1}$ in February and March, based on a study by Zimnoch et al. (2014).

\subsubsection{Top-down assessment of $\mathrm{CO}_{2}$ and $\mathrm{CH}_{4}$ fluxes using measurements of mixing layer height}

Diurnal changes in the dynamics of vertical mixing within the PBL, in combination with NBL height measurements, can be also applied for the assessment of surface fluxes of investigated 
trace gases. The rate of nocturnal increase of atmospheric concentrations of trace gases within the NBL is controlled by the mixing layer height, according to the mass balance equation (Zimnoch et al. 2010):

$$
H \frac{d\langle c\rangle}{d t}=F_{\text {in }}-F_{\text {out }},
$$

where:

$H \quad$ height of the mixing layer,

$\langle c\rangle \quad$ mean concentration within NBL,

$F_{\text {in }} \quad$ surface flux of the analyzed trace gas,

$F_{\text {out }}$ flux of the analyzed trace gas associated with removal processes (horizontal and vertical transport). For nights with low wind speed $\left(<1 \mathrm{~m} \mathrm{~s}^{-1}\right)$ and the adopted frequency of measurements, this term can be neglected.

During stable atmospheric conditions with low wind speeds, a distinct vertical gradient of trace gas concentration is established within the NBL. As measurements are performed close to the surface at the height of ca. $20 \mathrm{~m}$, a correction factor relating the average increase of the concentration within the NBL $(d<C>/ d t)$ to the increase of this concentration, observed at the measurement height, is required:

$$
F_{\text {in }}=\frac{H}{k} \cdot \frac{d c_{\text {surf }}}{d t}
$$

where:

$k \quad$ correction factor,

$c_{\text {surf }}$ concentration of the measured trace gas at the adopted measurement height.

Application of the approach, based on simplified atmospheric budget of these gases, linked to measurements of NBL height, was performed from May 2005 to May 2009. The correction factor $\mathrm{k}$ in Eq. (11) was calculated using numerical simulation of vertical profiles of atmospheric ${ }^{222} \mathrm{Rn}$, along with the EMEP atmospheric model (Zimnoch et al. 2014). The NBL height $H$ was monitored using VDS sodar. Details of the approach can be found in Zimnoch et al. (2010).

A summary of presented methods and their area of application can be seen in Table 1 .

\section{Results and discussion}

\subsection{Partitioning of $\mathrm{CO}_{2}$ budget in the urban atmosphere}

Results of application of the method described in Sect. 2.2.1 are presented in Fig. 2.

The data presented in Fig. 2 show a clear seasonal cycle of $\delta^{13} \mathrm{C}_{\text {src }}$ with minimum values (ca. $-40 \%$ ) observed during winter and maximum values (ca. $-25 \%$ ) during summer. Most of the data gathered during the summer points to signatures close to biogenic respiration and car traffic values, suggesting biospheric respiration flux as an important source of $\mathrm{CO}_{2}$ in the city at this time of the year. It is also possible to obtain such values by mixing methane and coal burning sources, but independent results of radiocarbon balance show that during 
Table 1 The summary of methods presented in the paper

\begin{tabular}{|c|c|c|c|c|}
\hline No. & Name & Calculated parameter & Input parameters & Application \\
\hline 1 & $\begin{array}{l}\text { Two component } \\
\text { mixing approach }\end{array}$ & $\begin{array}{l}\text { Isotopic signature of } \\
\text { the mean emission } \\
\text { source }\end{array}$ & $\begin{array}{l}\text { Atmospheric } \mathrm{CO}_{2} / \mathrm{CH}_{4} \\
\text { concentration and its } \\
{ }^{13} \mathrm{C} \text { isotopic } \\
\text { composition }\end{array}$ & $\begin{array}{l}\text { Identification of the } \\
\text { dominant local } \\
\mathrm{CO}_{2} / \mathrm{CH}_{4} \text { source }\end{array}$ \\
\hline 2 & $\begin{array}{l}\text { Three component } \\
\text { mixing approach }\end{array}$ & $\begin{array}{l}\text { Anthropogenic and } \\
\text { biogenic } \mathrm{CO}_{2} \\
\text { component }\end{array}$ & $\begin{array}{l}\text { Atmospheric } \mathrm{CO}_{2} \\
\text { concentration and } \\
\text { radiocarbon content in } \\
\text { the urban and } \\
\text { background } \\
\text { atmosphere }\end{array}$ & $\begin{array}{l}\text { Calculation of the } \\
\text { contribution of } \\
\text { anthropogenic and } \\
\text { biogenic emission in } \\
\text { the urban atmospheric } \\
\mathrm{CO}_{2} \text { load }\end{array}$ \\
\hline 3 & $\begin{array}{l}\text { Radon-based } \\
\text { top-down night flux } \\
\text { assessment }\end{array}$ & $\mathrm{CO}_{2} / \mathrm{CH}_{4}$ flux & $\begin{array}{l}\text { Atmospheric } \mathrm{CO}_{2} / \mathrm{CH}_{4} \\
\text { and }{ }^{222} \mathrm{Rn} \\
\text { concentration }\end{array}$ & $\begin{array}{l}\text { Estimation of the night } \\
\text { surface flux of selected } \\
\text { trace gases, } \\
\text { representing city size } \\
\text { footprint }\end{array}$ \\
\hline 4 & $\begin{array}{l}\text { PBL height-based } \\
\text { top-down night flux } \\
\text { assessment }\end{array}$ & $\mathrm{CO}_{2} / \mathrm{CH}_{4}$ flux & $\begin{array}{l}\text { Atmospheric } \mathrm{CO}_{2} / \mathrm{CH}_{4} \\
\text { and PBL height }\end{array}$ & $\begin{array}{l}\text { Estimation of the night } \\
\text { surface flux of selected } \\
\text { trace gases, } \\
\text { representing city size } \\
\text { footprint }\end{array}$ \\
\hline
\end{tabular}

summer, anthropogenic source contribution to the atmospheric load is very small (3-6 ppm); on the other hand, the chamber measurements performed in the city show the significant biospheric activity, for results of both analyses to be consistent. Gradual decrease of $\delta^{13} \mathrm{C}_{\mathrm{src}}$ values during autumn reflects decreasing strength of biospheric respiration and growing consumption of methane for heating purposes. It is apparent from Fig. 2 that burning of methane may constitute up to $50 \%$ of total $\mathrm{CO}_{2}$ emissions in the local atmosphere of Krakow in winter. This reflects a growing role of this fuel in the mix burned within the city limits. Twenty years ago, most houses in the city were heated by coal in the fireplaces, whereas recently, a significant part has been upgraded to more ecologic natural gas heating systems or connected to the city central heating network.

It is also apparent from Fig. 2 that from time to time, coal burning is a dominant source of $\mathrm{CO}_{2}$. Analysis of one episode is presented in Fig. 3.
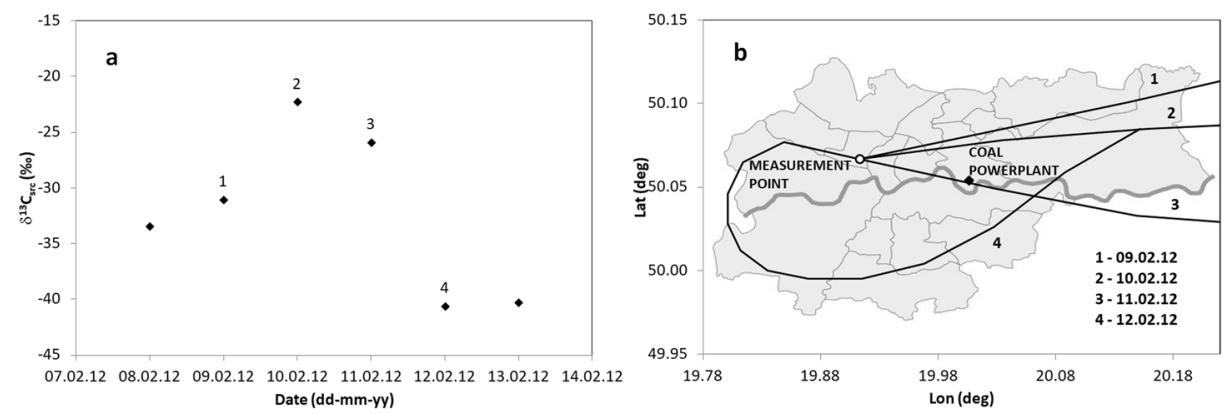

Fig. 3 Example of synoptic event demonstrating impact of high-emission point source of $\mathrm{CO}_{2}$ on the concentration of this gas measured close to the ground in Krakow (see text for details). The left panel demonstrates change of isotopic signature of mean $\mathrm{CO}_{2}$ source observed at the measurement point to values characteristic for coal burning (points 2 and 3). The right panel shows air mass circulation change. The elevated values of isotopic signatures correspond to air masses passing over the power plant before reaching the measurement point 
Back trajectory calculations done by the HySplit model (Draxler and Rolph 2011) showed that during the episode of high $\delta^{13} \mathrm{C}_{\mathrm{src}}$ values observed from 10 to 12 February 2012, the direction of air mass inflow to the monitoring site changed from northeast to southeast. During this time, the monitoring station was partly under direct influence of emissions originating from the Krakow power plant (black dot on the map in Fig. 3b) and the isotopic signature of atmospheric $\mathrm{CO}_{2}$ observed in this period moved to values close to $-24 \%$ o (characteristic for hard coal burning). With prevailing westerly circulation in Krakow, such situations are not common. Nevertheless, the presented case illustrates a possible influence of strong, highemission point sources of $\mathrm{CO}_{2}$ located in the city on local atmospheric $\mathrm{CO}_{2}$ budget.

Similar calculations and measurements of methane showed that carbon isotope signature of the mean source of $\mathrm{CH}_{4}$ obtained from the Keeling plot $\left(\delta^{13} \mathrm{C}_{\mathrm{src}}=-54.2 \%\right.$ o $)$ agree with the mean value of $\delta^{13} \mathrm{C}$ analyses of methane distributed in the city gas network $\left(\delta^{13} \mathrm{C}_{\mathrm{CH} 4}=-54.4\right.$ $\pm 0.6 \%$ ). This similarity points to network leakages as the main local source of methane in the Krakow area (Kuc et al. 2003). The amplitude of daily variations of $\mathrm{CH}_{4}$ mixing ratios was used to assess average flux of $\mathrm{CH}_{4}$ for the Krakow metropolitan area from 1996 to 1997. The estimated emission flux of $\mathrm{CH}_{4}$ for the entire city was on the order of $140 \mu \mathrm{mol} \mathrm{m} \mathrm{m}^{-2} \mathrm{~h}^{-1}$.

The results of $\mathrm{CO}_{2}$ apportionment using Eqs. (7)-(8) in the urban atmosphere of Krakow from 2005 to 2010 are presented in Fig. 4.

The fossil fuel-derived component of the $\mathrm{CO}_{2}$ budget varies from few ppm during the summer, up to ca. 20 ppm during winter months. The biospheric component varies between ca.
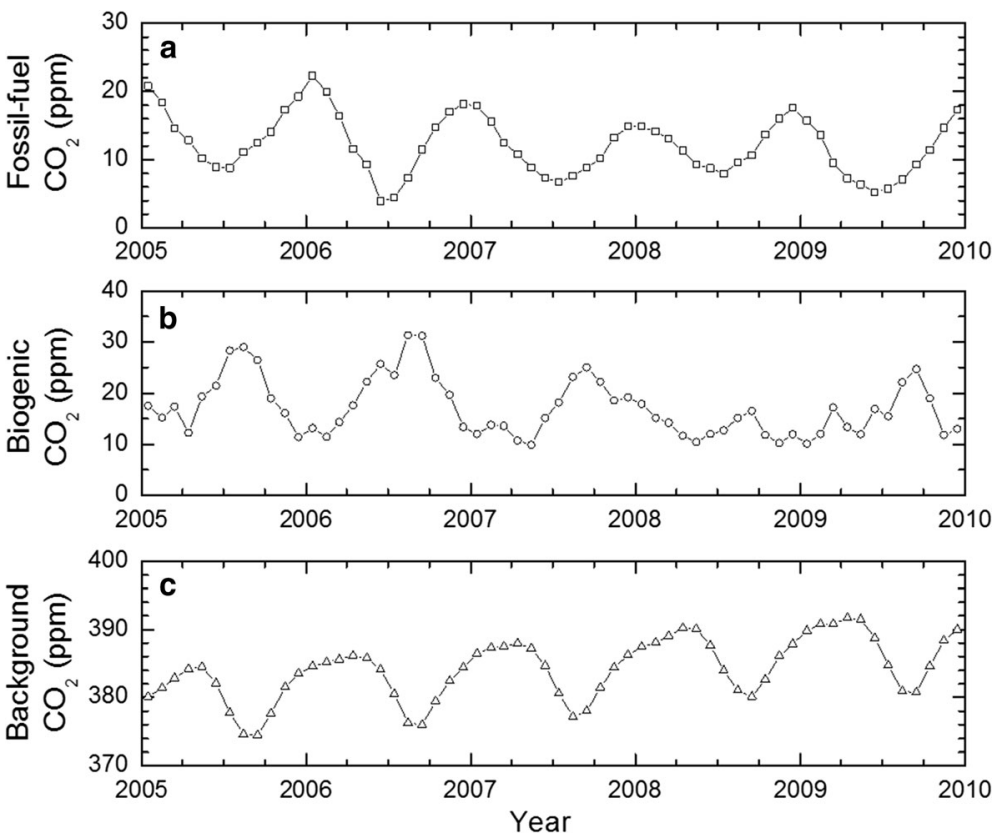

Fig. 4 Partitioning of atmospheric $\mathrm{CO}_{2}$ load in the urban atmosphere of Krakow: a monthly means of the fossil fuel-related component $\left(\mathrm{C}_{\text {foss }}\right)$ and $\mathbf{b}$ monthly means of the biogenic component $\left(\mathrm{C}_{\mathrm{bio}}\right)$, both derived using isotope mass balance approach (see text for details). Monthly means of the marine regional $\mathrm{CO}_{2}$ background are shown for comparison (c) The uncertainties of $\mathrm{c}_{\text {foss }}$ and $\mathrm{c}_{\text {bio }}$ components calculated using the error propagation method are equal to ca. $2 \mathrm{ppm}$, while the marine background values show an uncertainy equal to $0.1 \mathrm{ppm}$. Figure reprinted by permission of the publisher (Taylor and Francis Ltd., http://www.tandfonline.com) from (Zimnoch et al. 2012) 
10 and $30 \mathrm{ppm}$, with maximum values occurring in summer and early autumn. It is interesting to note that, contrary to rural areas, the $\mathrm{CO}_{2}$ assimilation processes in an urban environment are analyzed as a monthly means, apparently unable to compensate fully for the biospheric respiration, resulting in the positive net $\mathrm{CO}_{2}$ flux into the atmosphere.

The second example concerns the application of Eqs. (7) and (8) to solve the $\mathrm{CO}_{2}$ budget on a daily time scale. Figure 5 shows the results of event sampling from 20/21 June 2007. Daily variations of $\mathrm{CO}_{2}$ mixing ratio, $\delta^{13} \mathrm{C}$, and radiocarbon content in $\mathrm{CO}_{2}$ are presented. Distinct diurnal variability of $\mathrm{CO}_{2}$ mixing ratios is observed, with the maximum (417 ppm) recorded late at night and the minimum $(391 \mathrm{ppm})$ the following afternoon. An initial increase of $\mathrm{CO}_{2}$ mixing ratio is accompanied by a drop of $\delta^{13} \mathrm{C}$ with an increase of $\Delta^{14} \mathrm{C}$. Later, during the day of 21 June, significantly lower $\Delta^{14} \mathrm{C}$ values were recorded.

The data shown in Fig. 5 were used to partition the $\mathrm{CO}_{2}$ budget in the local atmosphere of Krakow from 20/21 June 2007. Equations (5) and (6) were used to derive temporal evolution of individual components of this budget (fossil-fuel derived, biogenic, and regional $\mathrm{CO}_{2}$ background components). The results are presented in Fig. 6. The calculated contributions

Fig. 5 Concentration and carbon isotope composition of atmospheric $\mathrm{CO}_{2}$ recorded during measurement campaign carried out between 20 and 21 June 2007 in Krakow
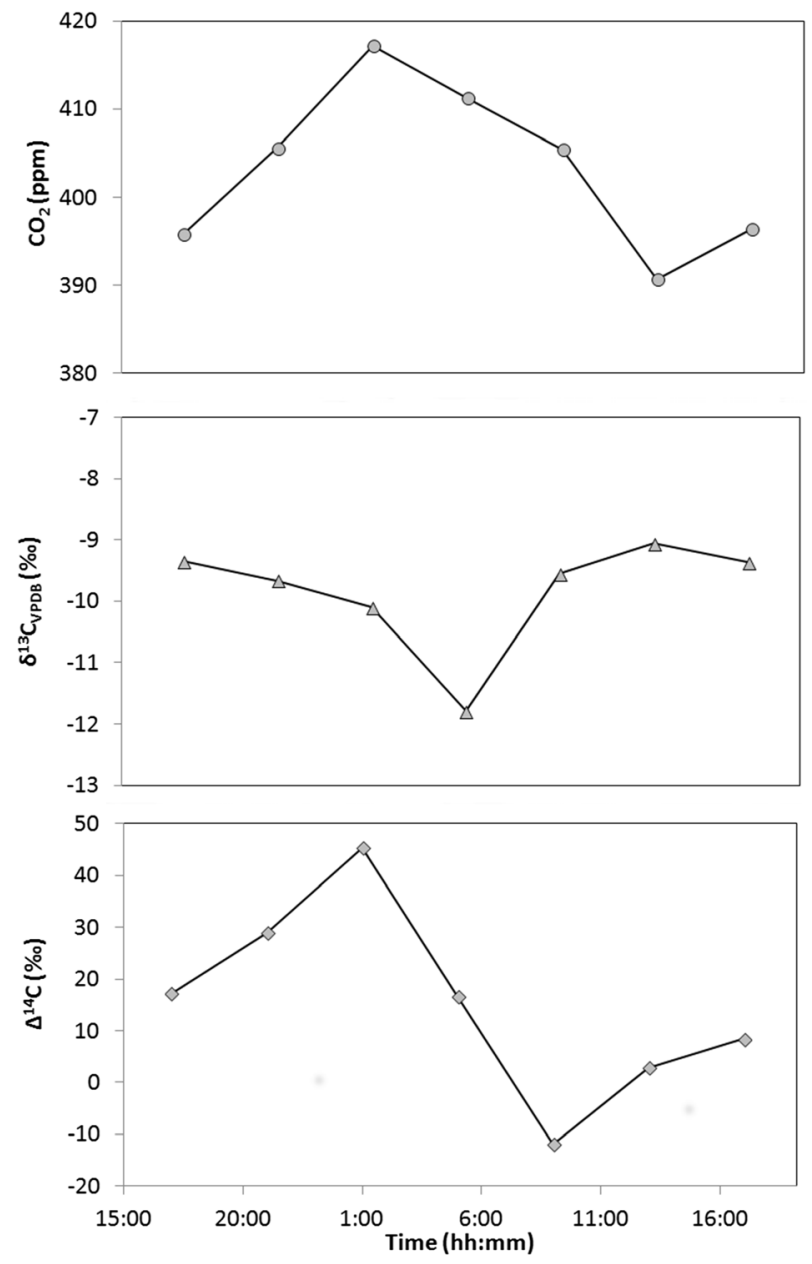
indicate a dominant role of biogenic $\mathrm{CO}_{2}$ emissions during the night, reaching maximum contribution of ca. $40 \mathrm{ppm}$. The nightly anthropogenic contribution is on the order of a few ppm. During the day, the biogenic contribution is reduced to values close to zero: this is because of the assimilation processes and anthropogenic emissions that dominate, increasing urban atmospheric $\mathrm{CO}_{2}$ load by up to $20 \mathrm{ppm}$.

\subsection{Top-down assessment of $\mathrm{CO}_{2}$ and $\mathrm{CH}_{4}$ fluxes using atmospheric ${ }^{222} \mathrm{Rn}$ concentration}

The results of the assessment described in Sect. 2.2.2 are presented in Figs. 7 and 8. There are some data gaps in both records, due to $\mathrm{GC}$ and radon monitor failures. Calculated night $\mathrm{CO}_{2}$ and $\mathrm{CH}_{4}$ fluxes reflect emissions from both natural and anthropogenic sources, located in the Krakow area. The calculated $\mathrm{CO}_{2}$ flux reveals seasonal variability, with maximum values reaching ca. $30 \mathrm{mmol} \mathrm{m}^{-2} \mathrm{~h}^{-1}$ during the summer and autumn months and minimum values of less than $10 \mathrm{mmol} \mathrm{m}^{-2} \mathrm{~h}^{-1}$ during the winter and early spring. The range of summer values of $\mathrm{CO}_{2}$ flux is in good agreement with direct soil $\mathrm{CO}_{2}$ flux measurements in Krakow from 2009 to 2013, using the static chamber method (Jasek et al. 2014), while the winter results are significantly higher compared to chamber measurements. This difference can be explained by different fluxes in these two methods. While chamber measurements quantify only the $\mathrm{CO}_{2}$ flux originating from autotrophic and heterotrophic respiration in the soil, the top-down assessment method also takes into account other sources and sinks. The most important is anthropogenic $\mathrm{CO}_{2}$ flux. During the summer, the energy demand and associated $\mathrm{CO}_{2}$ emissions are relatively low and can be easily compensated by the assimilation processes linked to the urban biosphere. During winter months, however, the $\mathrm{CO}_{2}$ emissions associated with energy production increase substantially, while the biospheric activity is almost nonexistent.

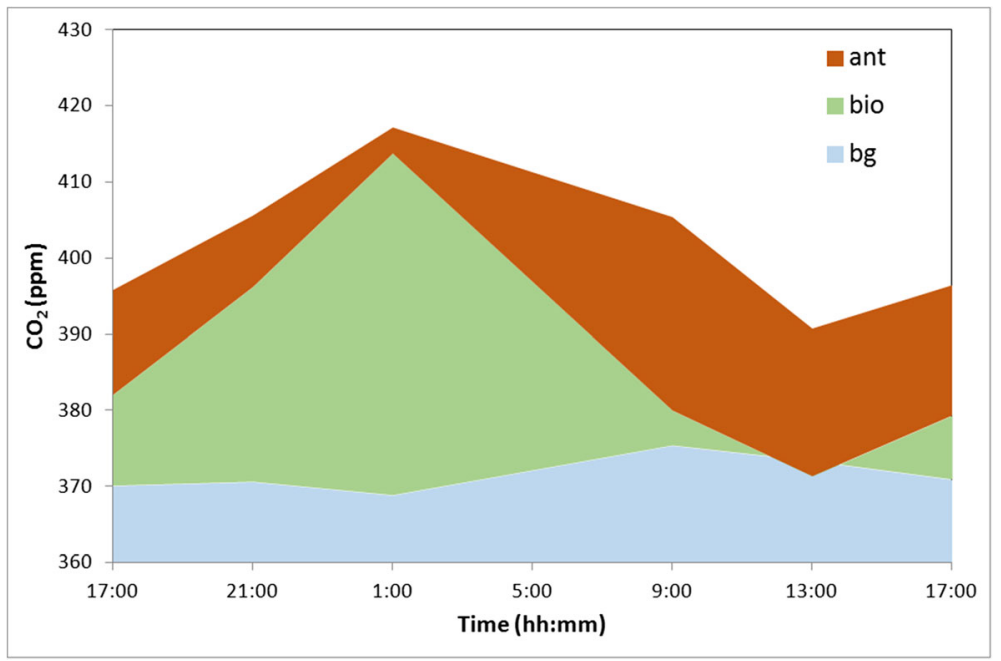

Fig. 6 Partitioning of atmospheric $\mathrm{CO}_{2}$ load over Krakow during 20/21 June 2007. Shown are fossil-fuel derived, biogenic, and regional $\mathrm{CO}_{2}$ background components. The uncertainties of calculated $\mathrm{c}_{\text {foss }}$ and $\mathrm{c}_{\mathrm{bio}}$ components using the error propagation method are equal to ca. $0.5 \mathrm{ppm}$, while the marine background value uncertainty is equal to $0.1 \mathrm{ppm}$ 


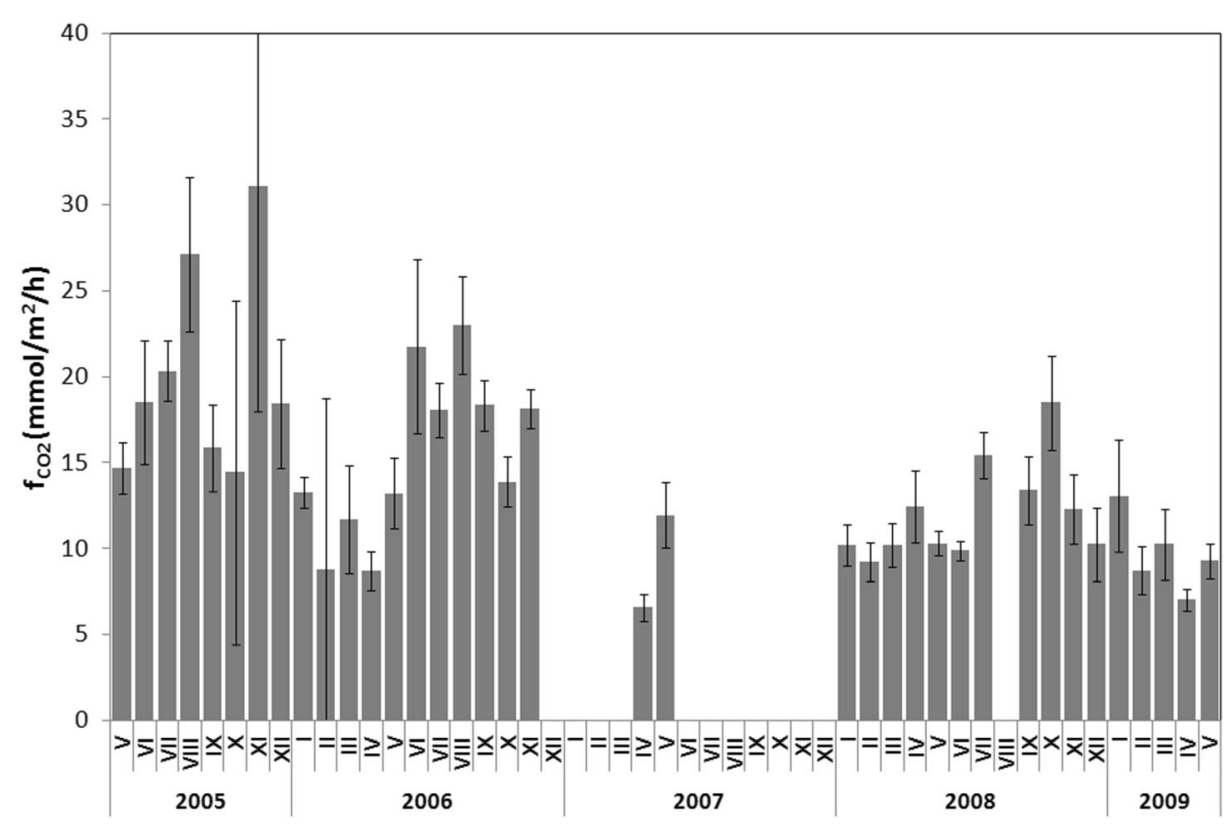

Fig. 7 Monthly means of surface-averaged $\mathrm{CO}_{2}$ flux density for the Krakow area, derived from parallel measurements of atmospheric $\mathrm{CO}_{2}$ and radon concentrations

Contrary to $\mathrm{CO}_{2}$ flux, the surface fluxes of methane (Fig. 8) do not reveal any distinct seasonality and, in contrast to chamber measurements, are positive. The monthly means of the calculated $\mathrm{CH}_{4}$ flux density scatter between ca. 70 and $200 \mu \mathrm{mol} \mathrm{m} \mathrm{m}^{-2} \mathrm{~h}^{-1}$, with a mean value

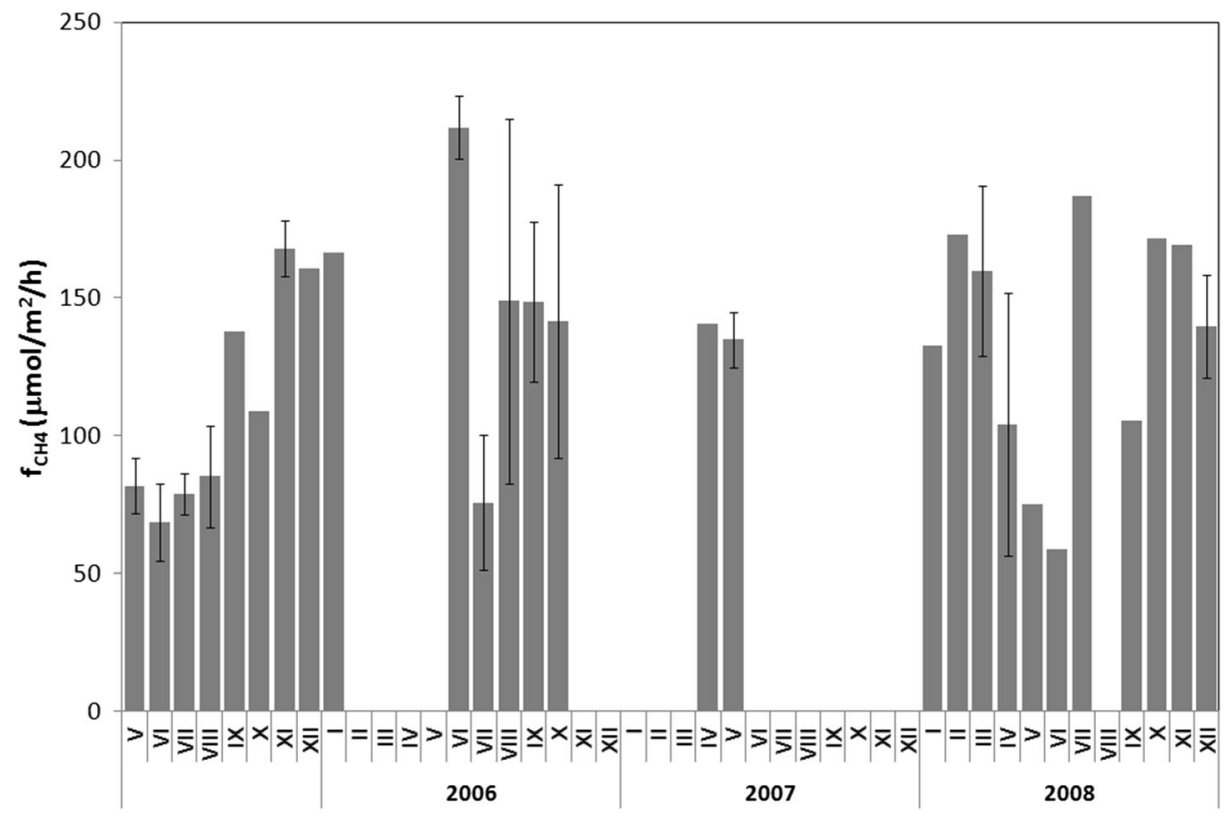

Fig. 8 Monthly means of surface-averaged $\mathrm{CH}_{4}$ flux for the Krakow area derived from parallel measurements of atmospheric $\mathrm{CH}_{4}$ and radon concentrations 
Table 2 Annual mean values of total $\mathrm{CH}_{4}$ flux calculated for Krakow agglomeration area, estimated by a topdown methodology described in Sect. 3.2 compared with emission values reported by two versions of the EDGAR emission database (Edgar 2013; Edgar 2011). The fluxes are reported in $\left(\mu \mathrm{mol} \mathrm{m} \mathrm{m}^{-2} \mathrm{~h}^{-1}\right)$

\begin{tabular}{lllll}
\hline Year & 2005 & 2006 & 2007 & 2008 \\
\hline Top-down assessment CH4_TOT & $111 \pm 14$ & $149 \pm 18$ & $138 \pm 3$ & $134 \pm 13$ \\
EDGAR v.4.2FT2010 CH4_TOT & $125 \pm 63$ & $129 \pm 65$ & $128 \pm 64$ & $127 \pm 64$ \\
EDGAR v.4.2 CH4_TOT & $343 \pm 172$ & $333 \pm 167$ & $324 \pm 162$ & $315 \pm 158$ \\
\hline
\end{tabular}

for the period shown in Fig. 8 , as equal to $131 \pm 8 \mu \mathrm{mol} \mathrm{m}{ }^{-2} \mathrm{~h}^{-1}$. It should be emphasized, however, that the data gaps in the record are much higher, and thus representative of the mean value is significantly lower when compared to $\mathrm{CO}_{2}$ flux estimates. Direct chamber measurements of soil $\mathrm{CH}_{4}$ flux performed in Krakow indicate small negative values ( 1 to $2 \mu \mathrm{mol} \mathrm{m} \mathrm{m}^{-2} \mathrm{~h}^{-1}$-not yet published as our data). Observed large difference between both methods points to a strong anthropogenic source of methane present in Krakow.

To validate this methodology as a complementary method to the bottom-up estimates, annual mean values calculated on results presented in Fig. 8 have been compared to total $\mathrm{CH}_{4}$ emission flux reported by EDGAR emission database versions 4.2 and 4.2FT2010 (Edgar 2011; 2013). EDGAR emissions were calculated for the rectangular area of size $29 \times 33 \mathrm{~km}$ centered on the closest possible location to the measurement point. The assumed area for EDGAR flux average calculation is in good agreement with the estimated footprint for the topdown method. Obtained total $\mathrm{CH}_{4}$ flux values are presented in Table 2.

An expert judgment of uncertainty estimates for total methane emission for the EDGAR database reported by Olivier et al. (1999) as equal to ca. 50\%. Assuming reported uncertainty

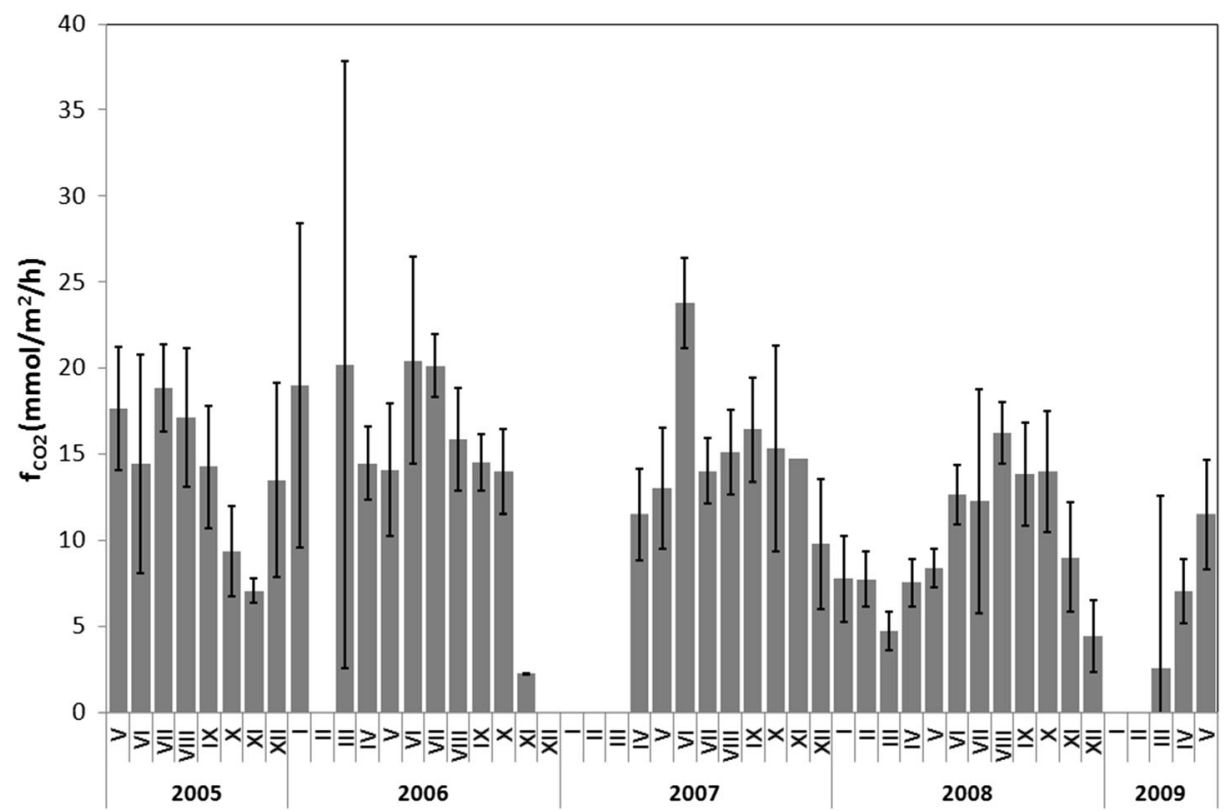

Fig. 9 Monthly means of surface-averaged $\mathrm{CO}_{2}$ flux density for the Krakow area, derived from the atmospheric balance method (see text for details). Figure reprinted from Zimnoch et al. (2010), based on creative commons license 


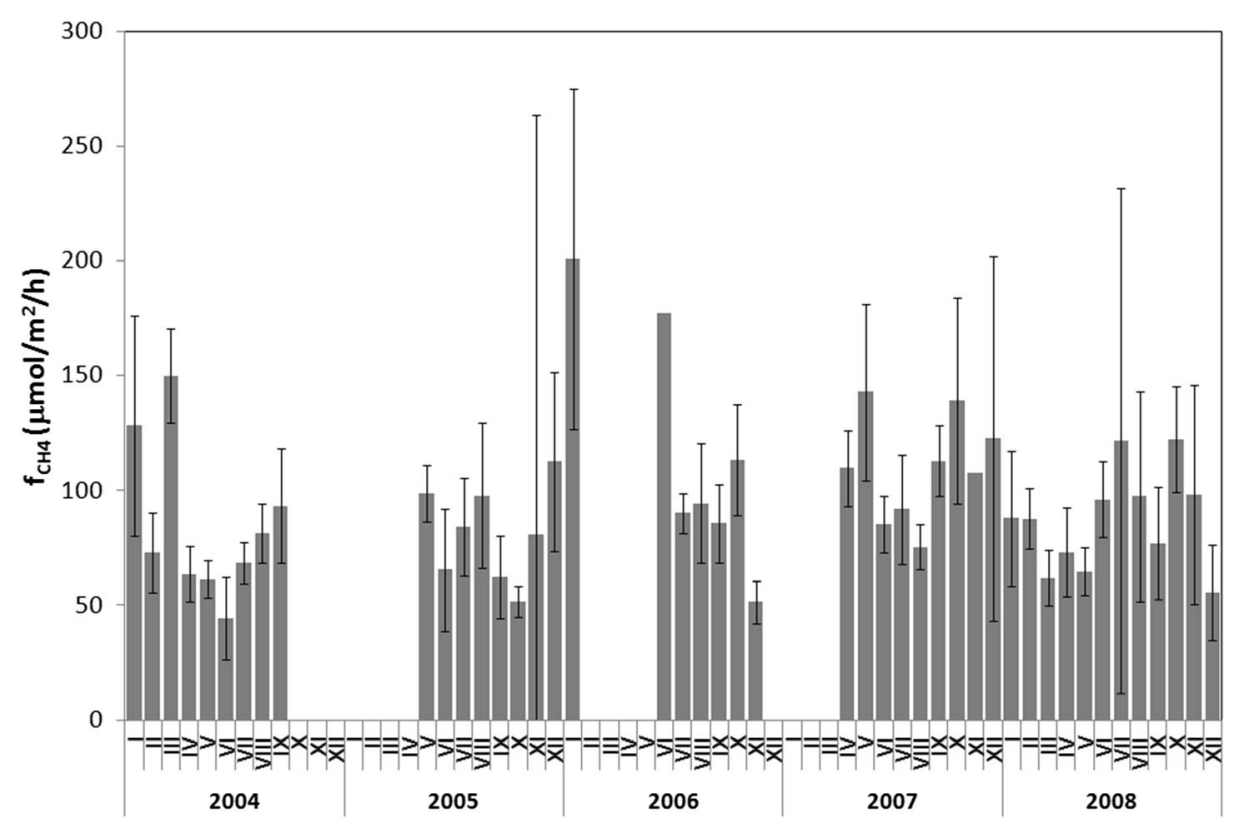

Fig. 10 Monthly means of surface-averaged $\mathrm{CH}_{4}$ flux density for the Krakow area, derived from the atmospheric balance method (see text for details). Figure reprinted from Zimnoch et al. (2010), based on creative commons license

(error bars in Fig. 8 and EDGAR estimates), the top-down emission fluxes agree well with values reported in version 4.2FT2010 of the EDGAR database; however, there is a significant difference when comparing it to version 4.2. This demonstrates the usefulness of the presented top-down method as complementary to bottom-up estimates.

\subsection{Top-down assessment of $\mathrm{CO}_{2}$ and $\mathrm{CH}_{4}$ fluxes using sodar mixing height measurements}

The calculated monthly mean surface fluxes of $\mathrm{CO}_{2}$ (Fig. 9) reveal distinct seasonal changes, with a minimum of ca. $2 \mathrm{mmol} \mathrm{m}^{-2} \mathrm{~h}^{-1}$ occurring during the winter (December to March) and a maximum of ca. $20 \mathrm{mmol} \mathrm{m}^{-2} \mathrm{~h}^{-1}$ during the summer (July to August). Relative uncertainty of the monthly mean $\mathrm{CO}_{2}$ fluxes as derived from simplified atmospheric budget, varying between ca. 1 and $87 \%$ of the calculated value. The mean values representing the analyzed period obtained by both methods using radon as a tracer and PBL height measurements (13.74 $\pm 0.76 \mathrm{mmol} \mathrm{m}^{-2} \mathrm{~h}^{-1}$ and $12.21 \pm 0.87 \mathrm{mmol} \mathrm{m}^{-2} \mathrm{~h}^{-1}$ ) agree within standard uncertainty; however, large differences are observed for individual monthly mean values. This can be the effect of different data selection procedures based on the correlation between radon and $\mathrm{CO}_{2}$ increase, in the case of the radon tracer method, wind speed, and PBL height variability criteria in the PBL method. Such an effect tends to treat both as qualitative assessment methods, which are more reliable for longer averaging periods. While both methods produce comparable results and variability, the decision as to which should be used depends on the availability of the data.

Monthly means of the calculated $\mathrm{CH}_{4}$ flux scatter between ca. 50 and $200 \mu \mathrm{mol} \mathrm{m} \mathrm{m}^{-2} \mathrm{~h}^{-1}$ (Fig. 10), with relative uncertainty of the mean values varying between 10 and $227 \%$. The 
mean $\mathrm{CH}_{4}$ flux calculated for the analyzed period (May 2005 to December 2008) is equal to $97.2 \pm 5.4 \mu \mathrm{mol} \mathrm{m}{ }^{-2} \mathrm{~h}^{-1}$. The quoted uncertainty represents one standard deviation of the mean value. The mean values obtained by both methods agree within expanded uncertainty with coverage factor $k=3$. Multiplying the mean $\mathrm{CH}_{4}$ flux by the surface area of the city $\left(326.8 \mathrm{~km}^{2}\right)$ leads to the mean annual emission of methane into the atmosphere in Krakow, on the order of $(6.2 \pm 0.4) \times 10^{6} \mathrm{~m}^{3}$ year ${ }^{-1}$. Previous studies (Kuc et al. 2003) have shown leakages of the city gas network as a main anthropogenic source of methane in Krakow. The assessment of $\mathrm{CH}_{4}$ flux for the period 1996 to 1997 (ca.140 $\mu \mathrm{mol} \mathrm{m}^{-2} \mathrm{~h}^{-1}$ ), compared to the value obtained from 2005 to 2008 (ca. $97 \mu \mathrm{mol} \mathrm{m}{ }^{-2} \mathrm{~h}^{-1}$ ), demonstrates reduction of natural gas leakages by $30 \%$ over 10 years.

\section{Summary and conclusions}

Urban centers are important elements of the global carbon cycle. Their relevance will likely increase in the future, with continuing transformation of the world's population from a rural to urban one. We must gain a deeper understanding of carbon cycling in the urban environment to design appropriate strategies to control emissions and mitigate local and global climate changes from increased release of anthropogenic greenhouse gases into the atmosphere.

The above-presented overview of long-term investigations in Krakow agglomeration along with atmospheric observations reveals the potential of this approach for quantifying atmospheric loads and surface fluxes of major greenhouse gases in complex urban environments. Presented methods aimed to quantify atmospheric loads and fluxes of $\mathrm{CO}_{2}$ and $\mathrm{CH}_{4}$, based on the application of natural isotope tracers; observations of PBL height demonstrates the topdown approach complementing the widely used bottom-up methodology of reporting emissions of greenhouse gases based on emission statistics. Such methods combined with groundlevel measurements may be used for the monitoring of the efficiency of long term mitigation strategies. Moreover, supplementing them by high-resolution dispersion modeling provides an independent tool for policy-makers to test the effectiveness of potential climate change mitigation scenarios on a local urban scale.

Funding information The work has been partially supported by EU projects EUROHYDROS and CARBOEUROPE, grants of the Ministry of Science and Higher Education (Project Nos. 2256/B/P01/2007/33 and 4132/B/T02/2008/43) and the statutory funds of the AGH University of Science and Technology (Project No. 11.11.220.01/1). The authors thank four anonymous reviewers for detailed and critical comments, which significantly improved the manuscript.

Open Access This article is distributed under the terms of the Creative Commons Attribution 4.0 International License (http://creativecommons.org/licenses/by/4.0/), which permits unrestricted use, distribution, and reproduction in any medium, provided you give appropriate credit to the original author(s) and the source, provide a link to the Creative Commons license, and indicate if changes were made.

\section{References}

Alvarez RA, Pacala SW, Windbrake JJ, Chameides WL, Hamburg SP (2014) Greater focus needed on methane leakage from natural gas infrastructure. Proc Natl Acad Sci U S A 109:6435-6440

Boden T, Anders B (2015) CDIAC: cdiac.ess-dive.lbl.gov/trends/emis/meth_reg.html) (downloaded April 2018) 
Bun R, Nahorski Z, Horabik-Pyzel J, Danylo O, Charkovska N, Topylko P, Halushchak M, Lesiv M, Striamets O (2018) High resolution spatial inventory of GHG emissions from stationary and mobile sources in Poland: summarized results and uncertainty analysis. Mitig Adapt Strateg Glob Chang. https://doi.org/10.1007 /s11027-018-9791-2

Chmura L, Rozanski K, Necki JM, Zimnoch M, Korus A, Pycia M (2008) Atmospheric concentrations of carbon dioxide in southern Poland: comparison of mountain and urban environments. Pol J Environ Stud 17:859-867

Coplen T (1996) New guidelines for reporting stable hydrogen, carbon and oxygen isotope-ratio data. Geochim Cosmochim Acta 60:3359-3360

Danylo O, Bun R, See L, Topylko P, Xianguang X, Charkovska N, Tymków P (2015) Accounting uncertainty for spatial modeling of greenhouse gas emissions in the residential sector: fuel combustion and heat production. Proceedings of the 4th International Workshop on Uncertainty in Atmospheric Emissions, Systems Research Institute, Polish Academy of Sciences, Warszawa, Poland, ISBN 83-894-7557-X, pp 193-200

de Jong AF, Mook WG (1982) An anomalous Suess effect above Europe. Nature 298:641-644

Demény A, Haszpra L (2002) Stable isotope compositions of $\mathrm{CO}_{2}$ in background air and at polluted sites in Hungary. Rapid Commun Mass Spectrom 16:797-804

Dörr H, Kromer B, Levin I, Münnich KO, Volpp JJ (1983) $\mathrm{CO}_{2}$ and ${ }^{222} \mathrm{Rn}$ as tracers for atmospheric transport. J Geophys Res 88:1309-1313

Draxler RR, Rolph GD (2011) HYSPLIT (hybrid single-particle Lagrangian integrated trajectory) model. NOAA Air Resources Laboratory, Silver Spring http://ready.arl.noaa.gov/HYSPLIT.php

EDGARv4.2 (2011) European Commission, Joint Research Centre (JRC)/Netherlands Environmental Assessment Agency (PBL). Emission Database for Global Atmospheric Research (EDGAR), release version 4.2. http://edgar.jrc.ec.europa.eu, (downloaded Jan 2017)

EDGARv4.2FT1010 (2013) European Commission, Joint Research Centre (JRC)/Netherlands Environmental Assessment Agency (PBL). Emission Database for Global Atmospheric Research (EDGAR), release EDGARv4.2 FT2010, http://edgar.jrc.ec.europa.eu (downloaded Jan 2017)

EDGARv4.3 (2015) European Commission, Joint Research Centre (JRC)/PBL Netherlands Environmental Assessment Agency. Emission Database for Global Atmospheric Research (EDGAR), release version 4.3. http://edgar.jrc.ec.europe.eu (downloaded 01 Sep 2016)

Gioli B, Toscano P, Lugato E, Matese A, Miglietta F, Zaldei A, Vaccari FP (2012) Methane and carbon dioxide fluxes and source partitioning in urban areas: the case study of Florence Italy. Environ Pollut 164:125-131

Górka M, Lewicka-Szczebak D (2013) One-year spatial and temporal monitoring of concentration and carbon isotopic composition of atmospheric $\mathrm{CO}_{2}$ in a Wrocław (SW Poland) city area. Appl Geochem 35:7-13

Górka M, Sauer PE, Lewicka-Szczebak D, Jędrysek MO (2011) Carbon isotope signature of dissolved inorganic carbon (DIC) in precipitation and atmospheric $\mathrm{CO}_{2}$. Environ Pollut 159:294-301

Goslar T, Czernik J (2000) Sample preparation in the Gliwice Radiocarbon Laboratory for AMS ${ }^{14} \mathrm{C}$ dating of sediments. Geochronometria 18:1-8

Gupta M, Douglass AR, Kawa S, Pawson S (2004) Use of radon for evaluation of atmospheric transport models: sensitivity to emissions. Tellus B 56:404 412. https://doi.org/10.1111/j.1600-0889.2004.00124.x

Gurney KR (2013) Beyond hammers and nails: mitigating and verifying greenhouse gas emissions. EOS 94: $199-200$

GUS 2016 Central Statistical Office of Poland, Information Portal bdl.stat.gov.pl (downloaded 28 Sep 2016)

Jasek A, Zimnoch M, Gorczyca Z, Smula E, Rozanski K (2014) Seasonal variability of soil $\mathrm{CO}_{2}$ flux and its carbon isotope composition in Krakow urban area, southern Poland. Isot Environ Health Stud 50:143-155. https://doi.org/10.1080/10256016.2014.868455

Jelen D (2012) Antropogeniczny dwutlenek węgla w atmosferze Krakowa (in Polish) (Anthropogenic carbon dioxide in the atmosphere of Krakow) PhD thesis, AGH-University of Science and Technology

Keeling CD (1960) The concentration and isotopic abundances of carbon dioxide in the atmosphere. Tellus XII: 200-203

Kotthaus S, Grimmond CSB (2012) Identification of micro-scale anthropogenic $\mathrm{CO}_{2}$, heat and moisture sources - processing eddy covariance fluxes for a dense urban environment. Atmos Environ 57:301-316

Kuc T (1991) Concentration and carbon isotopic composition of atmospheric $\mathrm{CO}_{2}$ in southern Poland. Tellus 43B:373-378

Kuc T, Rozanski K, Zimnoch M, Necki JM, Korus A (2003) Anthropogenic emissions of $\mathrm{CO}_{2}$ and $\mathrm{CH}_{4}$ in an urban environment. Appl Energy 75:193-203. https://doi.org/10.1016/S0306-2619(03)00032-1

Le Quéré C, Moriarty R, Andrew RM, Canadell JG, Sitch S, Korsbakken JI, Friedlingstein P, Peters GP, Andres RJ, Boden TA, Houghton RA, House JI, Keeling RF, Tans P, Arneth A, Bakker DCE, Barbero L, Bopp L, Chang J, Chevallier F, Chini LP, Ciais P, Fader M, Feely R, Gkritzalis T, Harris I, Hauck J, Ilyina T, Jain AK, Kato E, Kitidis V, Klein KG, Koven C, Landschützer P, Lauvset SK, Lefèvre N, Lenton A, Lima ID, Metzl N, Millero F, Munro DR, Murata A, Nabel JEMS, Nakaoka S, Nojiri Y, O'Brien K, Olsen A, Ono T, Pérez 
FF, Pfeil B, Pierrot D, Poulter B, Rehder G, Rödenbeck C, Saito S, Schuster U, Schwinger J, Séférian R, Steinhoff T, Stocker BD, Sutton AJ, Takahashi T, Tilbrook B, van der Laan-Luijkx IT, van der Werf GR, van Heuven S, Vandemark D, Viovy N, Wiltshire A, Zaehle S, Zeng N (2015) Global carbon budget. Earth Syst Sci Data 7:349-396. https://doi.org/10.5194/essd-7-349-2015

Levin I, Glatzel-Mattheier H, Marik T, Cuntz M, Schmidt M, Worthy DE (1999) Verification of German methane emission inventories and their recent changes based on atmospheric observations. J Geophys Res 104:3447-3456

Levin I, Born M, Cuntz M, Langendörfer U, Mantsch S, Naegler T, Schmidt M, Varlagin A, Verclas S, Vagenbach D (2002) Observations of atmospheric variability and soil exhalation rate of radon-222 at a Russian forest site. Tellus 54B:462-475

Levin I, Kromer B, Schmidt M, Sartorius H (2003) A novel approach for independent budgeting of fossil fuel $\mathrm{CO}_{2}$ over Europe by ${ }^{14} \mathrm{CO}_{2}$ observations. Geophys Res Lett 30:2194

Levin I, Hammer S, Kromer B, Meinhard F (2008) Radiocarbon observations in atmospheric $\mathrm{CO}_{2}$ : determining fossil fuel $\mathrm{CO}_{2}$ over Europe using Jungfraujoch observations as background. Sci Total Environ 391:211-216

Liu HZ, Feng JW, Jarvi L, Vesala T (2012) Four-year (2006 to 2009) eddy covariance measurements of $\mathrm{CO}_{2}$ flux over an urban area in Beijing. Atmos Chem Phys 12:7881-7892

McKain K, Wofsy SC, Nehrkorn T, Eluszkiewicz J, Ehleringer JR, Stephens BB (2012) Assessment of groundbased atmospheric observations for verification of greenhouse gas emissions from an urban region. Proc Natl Acad Sci U S A 109:8423-8428

McMeeking GR, Bart M, Chazette P, Haywood JM, Hopkins JR, McQuaid JB, Morgan WT, Raut JC, Ryder CL, Savage N, Turnbull JC, Coe H (2012) Airborne measurements of trace gases and aerosols over the London metropolitan region. Atmos Chem Phys 12:5163-5187

Meijer HA, Smidt HM, Perez E, Keizer MG (1996) Isotopic characterization of anthropogenic $\mathrm{CO}_{2}$ emissions using isotopic and radiocarbon analysis. Phys Chem Earth 21:483-487

Miroslaw J (1997) Stosunki izotopowe metanu w atmosferze Krakowa (in Polish) (Methane isotope ratios in the atmosphere of Krakow) PhD thesis, AGH-University of Science and Technology

Molnar M, Major I, Haszpra L (2010) Fossil fuel $\mathrm{CO}_{2}$ estimation by atmospheric ${ }^{14} \mathrm{C}$ measurement and $\mathrm{CO}_{2}$ mixing ratios in the city of Debrecen, Hungary. J Radioanal Nucl Chem 286:471-476

Monit-Air (2016) Project report: http://www.ekocentrum.krakow.pl/889,a,wyniki-inwentaryzacji.htm (downloaded May 2016)

Mook WG, van der Plicht J (1999) Reporting ${ }^{14} \mathrm{C}$ activities and concentrations. Radiocarbon 41:227-239

Necki JM, Schmidt M, Rozanski K, Zimnoch M, Korus A, Lasa J, Graul R, Levin I (2003) Six-year record of atmospheric carbon dioxide and methane at a high-altitude mountain site in Poland. Tellus 55B:94-104

Netzel P, Stano S, Zarebski M (1995) Vertical Doppler sodar (VDS). Wiad IMGW 18:119-125

Olivier JGJ, Bouwman AF, Berdowski JJM, Veldt C, Bloos JPJ, Visschedijk AJH, van der Maas CWM, Zandveld PYJ (1999) Sectoral emission inventories of greenhouse gases for 1990 on a per country basis as well as on $10 \mathrm{x}$ 10. Environ Sci Pol 2:241-264

Piringer M, Joffre S (eds) (2005) The urban surface energy budget and mixing height in European cities: data, models and challenges for urban meteorology and air quality. In: Final report of Working Group 2 of COST715 Action. Demetra Ltd. Publishers, Bulgaria

Rosicki M, Załupka M (2015) Inventories of domestic heating sources and their emissions in urban areasmethods, results and uncertainty. Proceedings of the $4^{\text {th }}$ International Workshop on Uncertainty in Atmospheric Emissions, ISBN 83-894-7557-X, pp 187-192

Rozanski K, Necki J, Chmura L, Sliwka I, Zimnoch M, Bielewski J, Galkowski M, Bartyzel J, Rosiek J (2014) Anthropogenic changes of $\mathrm{CO}_{2}, \mathrm{CH}_{4}, \mathrm{~N}_{2} \mathrm{O}, \mathrm{CFCl}_{3}, \mathrm{CF}_{2} \mathrm{Cl}_{2}, \mathrm{CCl}_{2} \mathrm{FCClF}_{2}, \mathrm{CHCl}_{3}, \mathrm{CH}_{3} \mathrm{CCl}_{3}, \mathrm{CCl}_{4}, \mathrm{SF}_{6}$ and $\mathrm{SF}_{5} \mathrm{CF}_{3}$ mixing ratios in the atmosphere over southern Poland. Geol Quart 58:673-684. https://doi. org/10.7306/gq.1163

Turnbull JC, Karion A, Fischer ML, Faloona I, Guilderson T, Lehman SJ, Miller BR, Miller JB, Montzka S, Sherwood T, Saripalli S, Sweeney C, Tans PP (2011) Assessment of fossil fuel carbon dioxide and other anthropogenic trace gas emissions from airborne measurements over Sacramento, California in spring 2009. Atmos Chem Phys 11:705-721

Tuzson B, Henne S, Brunner D, Steinbacher M, Mohn J, Buchmann B, Emmenegger L (2011) Continuous isotopic composition measurements of tropospheric $\mathrm{CO}_{2}$ at Jungfraujoch (3580 m a.s.1.), Switzerland: realtime observation of regional pollution events. Atmos Chem Phys 11:1685-1696. https://doi.org/10.5194 /acp-11-1685-2011

Vogel FR, Huang L, Ernst D, Giroux L, Racki S, Worthy DEJ (2013) Evaluation of a cavity ring-down spectrometer for in situ observations of $\left(\mathrm{CO}_{2}\right)-{ }^{13} \mathrm{C}$. Atmos Meas Tech 6:301-308

Widory D, Javoy M (2003) The carbon isotope composition of atmospheric $\mathrm{CO}_{2}$ in Paris. Earth Planet Sci Lett 215:289-298 
Zhang K, Fichter J, Kazil J, Wan H, Zhuo W, Griffiths AD, Sartorius H, Zahorowski W, Ramonet M, Schmidt M, Yver C, Neubert REM, Brunke EG (2011) Radon activity in the lower troposphere and its impact on ionization rate: a global estimate using different radon emissions. Atmos Chem Phys 11:7817-7838

Zimnoch M, Florkowski T, Necki J, Neubert R (2004) Diurnal variability of delta C-13 and delta O-18 of atmospheric $\mathrm{CO}_{2}$ in the urban atmosphere of Krakow, Poland. Isot Environ Health Stud 40:129-143

Zimnoch M, Godlowska J, Necki JM, Rozanski K (2010) Assessing surface fluxes of $\mathrm{CO}_{2}$ and $\mathrm{CH}_{4}$ in urban environment: a reconnaissance study in Krakow, southern Poland. Tellus 62B:573-580

Zimnoch M, Jelen D, Galkowski M, Kuc T, Necki JM, Chmura L, Gorczyca Z, Jasek A, Rozanski K (2012) Partitioning of atmospheric carbon dioxide over central Europe: insights from combined measurements of $\mathrm{CO}_{2}$ mixing ratios and their carbon isotope composition. Isot Environ Health Stud 48:421-433

Zimnoch M, Wach P, Chmura L, Gorczyca Z, Rozanski K, Godlowska J, Mazur J, Kozak K, Jericevic A (2014) Factors controlling temporal variability of near-ground atmospheric ${ }^{222} \mathrm{Rn}$ concentration over central Europe. Atmos Chem Phys 13:9567-9581 